\title{
Study on garbage disposal mode with low energy consumption for villages and towns in cold region
}

\author{
Yi Ma* and Tian-Yu Zhao \\ Harbin Institute of Technology, Harbin, China
}

\begin{abstract}
Through field research of typical villages and towns in China's northern cold region, this paper research energy consumption and resource recovery in the process of village and town garbage collection and disposal and organizes current situation and problems of village and town garbage collection and disposal. At present, village and town garbage collection and disposal means and thoughts are traditional and lag behind in China's northern cold region. There is the lack of garbage collection and disposal mode suitable for cold villages and towns. Thus, village and town resources are not effectively utilized, and residents' living environment is affected continuously. This paper selects two mature garbage disposal methods: sanitary landfill and incineration power generation. Meanwhile, energy consumption and ultimate emission utilization of two schemes in garbage collection and disposal links are overall compared to propose garbage collection and disposal mode with low energy consumption suitable for green villages and towns in cold region. Besides, various control indexes of village and town garbage disposal schemes are explained in detail in combination of specific conditions.
\end{abstract}

\section{Research background and objective}

Urban and rural garbage disposal system construction in China's cold region started late. The development of garbage disposal system at village and town level is in the hysteretic state, because construction policy inclines to urban area. Thus, most villages and towns stack various kinds of garbage at random. This affects long effects on production and ecological environment and endangers green and sustainable development of agricultural production area to some extent. Hence, construction of perfect village and town garbage disposal system is a key link to construct green villages and towns and also complies with overall requirements of new-type urbanization put forward in the 12th five-year plan - synchronous development of agricultural modernization, new rural construction and urbanization. Through field research and questionnaire survey of nine typical villages and towns in cold region, this paper analyzes village and town garbage disposal system features in combination of village and town economy as well as regional conditions, evaluates current garbage collection and disposal mode with green measurement standards such as energy consumption and resource recycling, and summarizes the problems and feasible solutions to village and town garbage disposal system in cold region.

\section{Features and problems of towns' garbage disposal system}

\subsection{Garbage disposal system features}

Regional feature: Due to different terrain and landform of village and town distribution area in cold region, agglomeration degree of village and town garbage disposal system has obvious differences. Average transport distance of $44.4 \%$ of villages and towns is above $10 \mathrm{~km}$ the largest average transport distance reaches $18.45 \mathrm{~km}$. Thus, this results in the rise in transport energy consumption in some villages and towns and then affects terminal disposal facility layout of garbage disposal system.

Climate feature: The lowest average monthly temperature of nine villages investigated is about $-16{ }^{\circ} \mathrm{C}$. There are 5 months with monthly average temperature below $0{ }^{\circ} \mathrm{C}$. Cold climate leads to the rise in energy consumption in the process of collection, transport and disposal of garbage disposal system. Meanwhile, the content of inorganic substance in garbage disposal under large rural population such as dust is high.

\subsection{Problems existing in garbage disposal system}

Garbage collection and transport: Service scope of village and town garbage collection and transport is insufficient; the proportion of garbage collection facilities allocated for village and town households within $70 \mathrm{~m}$ is $58.32 \%$. Regular (1-2 weeks) garbage clearance and collection efficiency is less than $50 \%$. The garbage in garbage collection points in 
villages is stacked in quantity. There is short of garbage collection facilities around households at the edge of villages and towns. The villages and towns which adopt garbage clearance trucks to regularly collect garbage only account for $33.3 \%$. In one word, garbage collection and transport of villages and towns in cold region are still in the starting stage; on the other hand, limited by insufficient development of garbage collection and recycling, recovery and recycling rate of village household garbage resources is 0 . Except large household appliances, metal and plastic bottles which depend on garbage stations in township, other garbage is still in the state of mixed collection and disposal.

Garbage disposal: Only $11.1 \%$ of existing garbage disposal facilities in the villages and towns investigated can reach sanitary landfill standard. Only S town adopts sanitary landfill means. The garbage is transported to $\mathrm{W}$ city landfill for uniform disposal. Most villages and towns adopt simple landfill method and lack necessary innocent treatment measures such as disinfection, deodorization and anti-penetration. Only $45.3 \%$ of village garbage transport to township landfill. Most villages stack garbage at will beside rivers or ditches without any disposal measures.

\section{Garbage collection and disposal mode with low energy consumption for green villages}

Survey results of nine villages and towns in cold region serve as research samples of garbage disposal mode with low energy mode for green villages and towns. Based on household garbage survey of villages and towns, this research predicts average daily garbage output within 15 years. Besides, the garbage disposal mode is evaluated in accordance with basic conditions of villages and towns in cold region, energy consumption in each disposal link and resource recycling rate, and each green control index of village and town garbage disposal in cord region is gained. The garbage involved in this research mainly includes household garbage. Agricultural production residua such as straw are overall disposed through mature methods such as returning to field and composting.

At present, household garbage disposal methods mainly involve three types: sanitary landfill, incineration power generation and composting. Their utilization ratios in China's urban garbage innocent treatment measures are about $81.2 \%, 14.4 \%$ and $4.4 \%$ respectively. Garbage composting plant is not the mainstream method due to technology and compost product sales. In view of village and town garbage output in cold region and regional economic foundation, it is feasible to independently construct sanitary landfill in villages and towns or depend on small and medium incineration power generation plants in superior counties and cities to dispose household garbage. Through comparing sanitary landfill and incineration power generation in terms of input energy and emission disposal in such links as garbage collection, transport and disposal, this paper overall evaluates garbage collection and disposal mode with low energy consumption suitable for green villages and towns in cold region.

\subsection{Survey of basic information about villages and towns and prediction of garbage output}

In line with statistical results of 150 questionnaires in each village and town, per-capita garbage output is higher in developed villages and towns in cold region. Per-capita garbage output in township is $0.6-0.7 \mathrm{~kg} / \mathrm{d}$. Per-capita garbage output in township is significantly higher than that in villages $(0.3-0.4 \mathrm{~kg} / \mathrm{d})$. This is because most peasant households compost and burn organic garbage to reduce garbage surplus.

Garbage disposal facilities should usually own the service life of 15-20 years, so garbage output within 15 years should be considered when village and town garbage is transported to sanitary landfill plant or depends on incineration power generation plant for disposal. According to garbage output of villages and towns as well as counties and cities, annual mean garbage output within 15 years is calculated as per annual mean $5 \%$ garbage growth rate. Garbage output of nine villages and towns within 15 years is $7.62-51.43 \mathrm{t} / \mathrm{d}$. Average daily garbage weight differs obviously. As per the provisions of construction standards of household garbage sanitary landfill disposal project, it belongs to class-4 50-150 t/d and garbage sanitary landfill plant below class- 4 scale. Garbage output of counties and cities is 302.10-549.42 t/ d. As per the provisions of construction standards of urban household garbage construction standards of project, it belongs to garbage incineration disposal plant of class-3 200-500 t/d scale. In the following, energy consumption values in each disposal link are taken according to garbage disposal engineering suitable for villages and towns as well as counties and cities.

\subsection{Situation assessment of garbage collection and disposal mode}

Main links of garbage disposal involve garbage transport to the disposal plant, garbage disposal and emission disposal. Main energy input includes oil consumption in garbage transport, water used in garbage disposal, electric power and heat supply of garbage electric power. The mean distance of garbage collection in the towns in cold area is below $7 \mathrm{~km}$. The distance of garbage collection tanks shall be below $150 \mathrm{~m}$ (according to survey). For residential buildings, a garbage collection tank should be set up within three units [1]. Therefore, the tricycle or minitype truck which adopts closed collection method is the best low energy consumption scheme for garbage collection in towns and villages. The trip from villages to township garbage transfer station is completed through light-duty compression garbage collector. This can guarantee the lowest energy consumption in the collection process and the highest garbage transport efficiency. This paper adopts minimum spanning tree method to calculate the shortest collection distance of garbage clearance and transport truck within the town. Fuel consumption in garbage transport is calculated according to fuel consumption for trucks in operation GB/T 4352-2007. For village and town sanitary landfill, it is just necessary to calculate diesel consumption in garbage transfer process. Garbage incineration disposal 
Table 1. Energy consumption of per-ton garbage in two disposal schemes.

\begin{tabular}{lcllll}
\hline & Scale $(\mathrm{t} / \mathrm{d})$ & Diesel $(\mathrm{kg} / \mathrm{t})$ & Water $\left(\mathrm{m}^{3} / \mathrm{t}\right)$ & Electricity $(\mathrm{kwh} / \mathrm{t})$ & Coal $(\mathrm{kg} / \mathrm{t})$ \\
\hline \multirow{3}{*}{ Sanitary landfill } & $10-15$ & 0.50 & 0.36 & 1.86 & 1.09 \\
& $25-30$ & 0.45 & 0.33 & 1.70 & 0.94 \\
Incineration & 50 & 0.42 & 0.32 & 1.60 & 0.79 \\
& $300-500$ & 2.20 & 2.07 & 51.20 & 1.54 \\
\hline
\end{tabular}

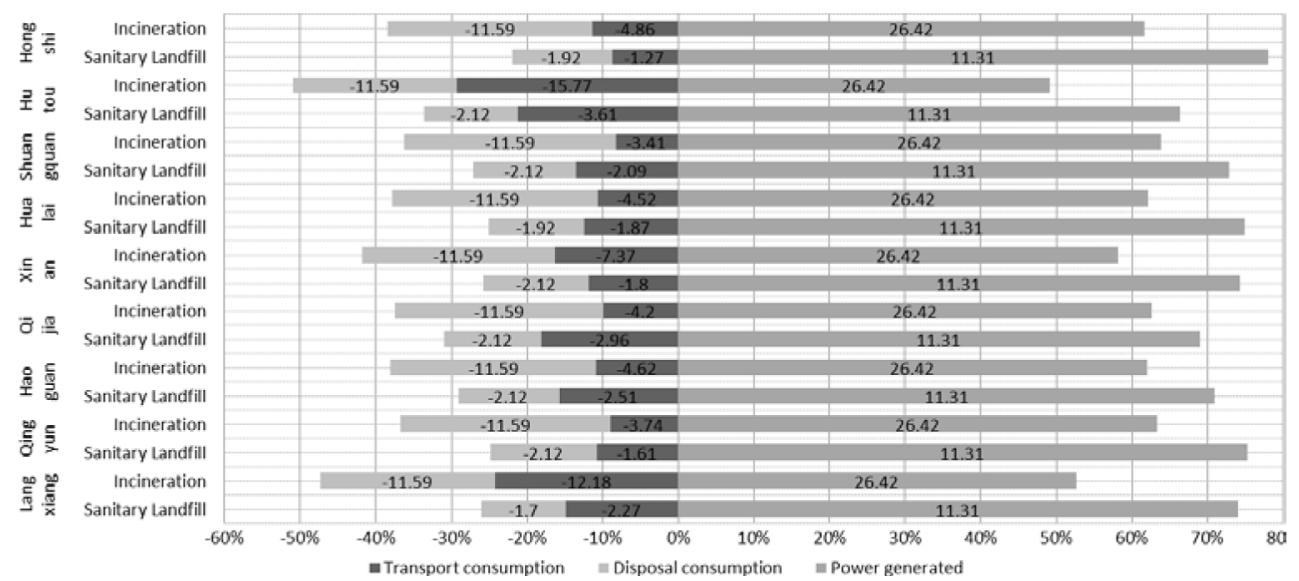

Fig. 1. Energy consumption and recycling for per-ton garbage disposal (stand coal kg/t).

mode also needs to increase the transport distance of transferring garbage to the superior or county city. Garbage transport truck adopts side compression type, with the loading volume of $5 \mathrm{~m}^{3}$ and fuel consumption of $15-19 \mathrm{~L} /$ $100 \mathrm{~km}$. See Table 1 for energy consumption in garbage disposal process.

Emissions generated from sanitary landfill mainly include $\mathrm{CH}_{4}$ and $\mathrm{CO}_{2}$, etc. Mature recycling mode is power generation with burning landfill gas or landfill gas liquidation. The utilization efficiency of landfill gas is about $30 \%$ [2]. Per-ton garbage can generate about $90 \mathrm{kwh}$ power. Garbage incineration can utilize waste heat for power generation or co-generation. Waste-heat utilization efficiency is about 25-40\%. Per-ton garbage can generate about $215 \mathrm{kwh}$ power.

Energy consumption is transformed to standard coal consumption according to general principles for calculation of the comprehensive energy consumption GBT2589-2008. Then, energy consumption and recycling of nine villages and towns in two garbage disposal schemes can be gained (Fig. 1). It can be seen from Figure 1 that per-ton garbage used for incineration power generation can generate energy amount of $26.42 \mathrm{~kg}$ standard coal. Only $11.31 \mathrm{~kg}$ standard coal can be gained from sanitary landfill gas recovery. Seeing from energy consumption contribution rate of two garbage collections and disposal scheme, energy consumption contribution rate of sanitary landfill is $72.84 \%$ on the average, while energy consumption contribution rate of garbage incineration is $59.4 \%$ on the average. Thus, perton garbage of sanitary landfill can gain higher recycling resource through less energy consumption.
Energy consumption contribution rate of two garbage disposals is mainly related to village garbage transport energy consumption and transport energy consumption of garbage incineration plant from the village and town to the superior county and city [3]. Energy consumption surplus of garbage incineration power generation in $\mathrm{L}$ and $\mathrm{H}$ town is significantly inferior to sanitary landfill mode. For X town, the two disposal modes differs little $(-0.07 \mathrm{~kg} / \mathrm{t})$. This is mainly because the three towns are too far from the nearest county or city $(85.8 \mathrm{~km}, 59.0 \mathrm{~km}$ and $46.9 \mathrm{~km}$, respectively). Town systems of some cold regions are loose, which results in high transport energy consumption. For the towns whose distance with the superior county or city is less than $10 \mathrm{~km}$, energy surplus difference value of garbage incineration mode significantly improves $(3.53 \mathrm{~kg} / \mathrm{t}, 4.4 \mathrm{~kg} / \mathrm{t}$ and $4.32 \mathrm{~kg} / \mathrm{t}$, respectively).

To sum up, garbage transport distance factor plays a key role in selecting village and town garbage disposal scheme in cold region. The villages and towns with garbage transport distance more than $40 \mathrm{~km}$ should choose construction of sanitary landfill, while the villages and towns with garbage transport distance less than $15 \mathrm{~km}$ should consider garbage incineration plant for overall disposal in the nearest county or city. The villages and towns with the garbage transport distance between $15 \mathrm{~km}$ and $40 \mathrm{~km}$ should make decisions according to specific conditions. Guiding indexes can be gained for energy consumption value of per-ton garbage based on the above contents. Energy consumption value of garbage disposal by sanitary landfill should be lower than $2.22 \mathrm{~kg} / \mathrm{t}$ (taking the mean value according to villages and towns investigated). 
For the villages and towns with loose systems, the range of indexes should increase $50 \%$. If garbage incineration power generation scheme us adopted, garbage transport distance should not exceed $40 \mathrm{~km}$. Diesel consumption for per-ton garbage transport should be below $2.75 \mathrm{~L} / \mathrm{t}$. finally, electric energy generation of per-ton garbage should not be below $215 \mathrm{kwh} / \mathrm{t}$.

\section{Conclusions}

Garbage disposal system of villages and towns in cold region is still in the starting state. Plentiful capital input is required to perfect garbage disposal system construction. Application policy and loan support are needed, on the other hand, it is necessary to solve problems from construction and operation features of village and town garbage disposal system. This paper gains feasibility scheme of village and town garbage disposal facilities under different conditions through comparative analysis of energy consumption and energy consumption surplus in each link of two mature garbage disposal schemes. This paper offers certain reference for village and town garbage collection and disposal system construction in cold region as well as operation balance. The construction involves spatial arrangement, traffic and spatial arrangement energy consumption of villages and towns, etc. In follow-up research, transport strategy of different disposal schemes, recycling and reusing of garbage emission still need in-depth research.

\section{References}

1. X.C. Zhou, L.Y. Xu, Z.F. Yang, Optimization of low-carbon municipal solid processing model, Acta Sci. Circumst. 32, 498 (2012)

2. W. Jiani, Research on the evaluation of small town's municipal solid waste treatment technology in Yunnan Province (Kunming University of Science and Technology, 2013)

3. L. Wenjing, S. Na, Z. Lingge, Life cycle assessment of domestic waste treatment in Dalian, Environ. Sanit. Eng. 17, $55(2009)$

Cite this article as: Yi Ma, Tian-Yu Zhao, Study on garbage disposal mode with low energy consumption for villages and towns in cold region, Renew. Energy Environ. Sustain. 1, 21 (2016) 